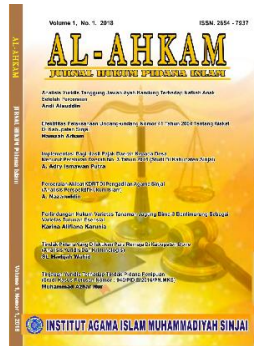

\title{
Critical Legal Studies Politik Etis Terhadap Mahar Politik Dalam Pembaharuan Hukum Pidana
}

\author{
Dewi Iriani $^{1}$, Lusiana Al Vionita ${ }^{2}$, Uswatul Khasanah ${ }^{3}$ \\ ${ }^{1}$ IAIN Ponorogo, Jl. Puspita Jaya, Pintu Jenangan, Ponorogo, Jawa Timur \\ ${ }^{2}$ IAIN Ponorogo, Jl. Puspita Jaya, Pintu Jenangan, Ponorogo, Jawa Timur \\ ${ }^{3}$ IAIN Ponorogo, Jl. Puspita Jaya, Pintu Jenangan, Ponorogo, Jawa Timur \\ Email : dewiiriani.iainponorogo@gmail.com Tlp :081327695238
}

\begin{abstract}
Abstrak
Penelitian ini bertujuan untuk mengetahui bagaiamana politik etis dalam mahar politik dan untuk mengetahui bagaimana pelaksanaan politik etis dalam pembaharuan hukum pidana mahar politik. Penelitian ini menggunakan metode pendekatan kualitatif, berupa yuridis normatif dengan data yang disajikan membahas permasalahan melalui analisa kasus dengan menggunakan teori critical legal studies dan pembaharuan hukum pidana sebagai pisau analisis. Jenis penelitian berupa metode libary / kepustakaan.. Hasil penelitian dan pembahasan 1) Politik etis dalam mahar politik Berdasarkan pandangan di atas teori hukum dapat dikategorikan dua model hukum yaitu pertama; jurisprudensi model berkaitan dengan asas aturan tertulis, kaidah, norma atau putusan hakim. Kedua menggunakan socialogi model terkait fenomena yang terjadi di masyarakat menjelang pemilu pada $\mathrm{H}-1$ banyaknya serangan fajar yang dilakukan oleh calon legislatif dan calon kepala daerah bertujuan untuk dapat memilih calon legilatif dan calon kepala daerah. .2) Pelaksanaan Politik Etis Dalam Pembaharuan Hukum Pidana Mahar Politik; Pembaharuan hukum pidana terkait mahar politik perlu dilakukan dengan beberapa alasan yang melandasinya, yaitu ; Sumber hukum materil terdiri dari: Landasan filosofis, yuridis, sosiologis yang berdasarkan filosofis Pancasila, sedangkan dari Sumber hukum formil Perlunya pembaruan hukum pidana dari segi sumber hukum formil terkait Undang-Undang No 7 tahun 2017 tentang Pemilu pasal 327 ayat 1 dan 2 tentang Pemilu terdapat batasan dalam pemberian dana kampanye.
\end{abstract}

Kata Kunci : Critical Legal Studies, Mahar Politik, Pembaharuan Hukum

\section{Pendahuluan}

Critical Legal Studies (CLS), sebagai nama payung bagi suatu arus pemikiran hukum di kalangan ahli hukum Amerika yang tidak puas dan menentang paradigma liberal yang sudah mapan dalam studi-studi hukum hukum atau jurisprudence. Gerakan/studi hukum kritis, meski hanya sebuah fenomena Amerika, mereka mencoba mengemas sebuah teori yang bertujuan melawan pemikiran yang sudah mapan khususnya mengenai norma-norma dan standar yang sudah built-in dalam teori dan praktik hukum yang ada selama ini, yang cenderung untuk diterima apa adanya (taken for granted), yaitu norma-norma dan standar hukum yang didasarkan pada premis ajaran liberal legal justice. Penganut aliran ini percaya bahwa logika dan struktur hukum muncul dari adanya power relationships dalam masyarakat. Kepentingan hukum adalah untuk mendukung kepentingan atau kelas dalam masyarakat yang membentuk hukum tersebut. dalam kerangka pemikiran ini, mereka yang kaya dan kuat menggunakan hukum sebagai instrument untuk melakukan penekanan-penekanan kepada masyarakat, 


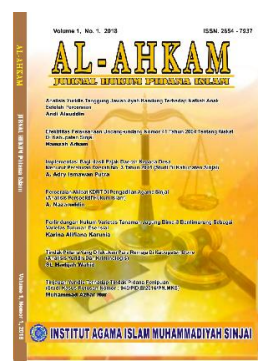

Al-Ahkam

Jurnal Hukum Pidana Islam

Volume 3, No. 1, 2021

ISSN (print) : 2654-7937

ISSN (online) : 2715-0313

Homepage : $\underline{\text { http://journal.iaimsinjai.ac.id/index.php/al-ahkam/index }}$

sebagai cara untuk mempertahankan kedudukannya.oleh karena itu hukum hanya diperlukan sebagai 'a collection of beliefs'.

Kebijakan keputusan yang dibuat oleh penguasa eksekutif maupun legislatif dalam membuat undang-undang, banyak hal yang harus diperbaiki atau revisi karena tidak memihak pada kepentingan rakyat dan hanya memihak pada golongan atas, maka harus dilakukan pembaharuan hukum. Menurut ajaran Roscue Poud sebagai ajaran realisme, pada khususnya melihat hukum sebagai alat untuk menciptakan hukum yang lebih efektif. Ajaran ini pula sering digolongkan sebagai social jurisprudence, yang berarti hukum senantiasa menjadi sarana pembaharuan setelah melihat praktik-praktik hukum dilapangan.

Bahwasanya politik erat kaitannya dengan penguasa, baik di eksekutif, legislative, maupun yudikatif. Yang mana politik etis ini dapat berperan dalam mengambil kebijakan keputusan undang-undang yang sangat pengaruh sekali hasilnya terhadap rakyat dan negara. Menurut Bambang Widjojanto, politik etis adalah proses nilai etis dalam mengelola sistem yang dibentuk untuk rakyat. ${ }^{1}$

Pembaharuan hukum tidak hanya pada pembuat undang-undang yaitu lembaga legislatif namun jika di lembaga eksekutif sebagai pembuat kebijakan yang diatur dalam peraturan pemerintah dan lembaga yudikatif sebagai badan peradilan yang memiliki kewenangan dalam membuat putusan jika ada yang melanggar undang-undang. Trias politika yang ada di Indonesia dalam suatu lembaga eksekutif legislatif, yudikatif. Pada lembaga eksekutif dan lembaga legislatif orang yang menduduki kekuasaan tersebut sebelumnya mereka harus melewati tahapan pemilu eksekutif (DPR, DPRD) dan legislatif pada Pemilu Kepala Daerah yang ada di wilayah Indonesia melakukan kontrak dengan pihak lain untuk memenangkan pemilu.

Kontrak yang dilakukan ini menjadi benih-benih korupsi. Dengan banyaknya pejabat pemerintah dari tingkat Gubernur, Bupati, Walikota maupun anggota DPR dan DPRD yang terjerat kasus korupsi. Dikarenakan pada waktu akan mendaftar bakal calon terikat kontrak dengan pihak lain untuk memenangkan pemilu inilah yang disebut dengan mahar politik. Sedangkan pengertian mahar politik adalah pemberian janji politik dari bakal calon kepada partai maupun pihak lain, sehingga partai dan pihak lain memberikan bantuan modal untuk berkampanye. Apabila menang maka akan bakal calon memberikan kompensasi berupa uang atau pemberian proyek. Selain itu di lembaga yudikatif juga sering adanya praktik suap. Para pihak yang berperkara sering kali memberikan suap untuk memenangkan perkaranya, ataupun untuk mengurangi hukuman yang seharusnya mereka terima. Melihat beberapa fakta diatas, para pemegang kekuasaan legislatif, eksekutif, dan yudikatif sangat tidak sesuai dengan politik etis

\section{Metode penelitian}

Penelitian ini menggunakan metode pendekatan kualitatif, berupa yuridis normatif dengan data yang disajikan membahas permasalahan melalui analisa kasus dengan menggunakan teori critical legal studies dan pembaharuan hukum pidana sebagai pisau analisis. Jenis penelitian berupa metode libary / kepustakaan. Sumber data penelitian ini berupa data primer adalah data utama yakini kasus mahar politik. Data sekunder berupa buku,

${ }^{1}$ Bambang Widjojanto, Politik Etis Dalam Pencegahan Tindak Pidana Korupsi, dalam Seminar Nasional Universitas Muhammadiah Ponorogo, 2 Maret 2019. 


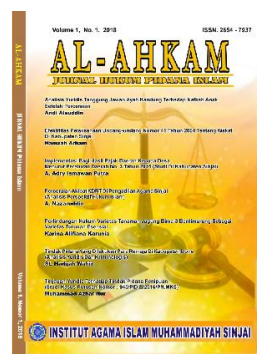

jurnal, penelitian, yang mengkaji Critical Legal Studies Politik Etis Tehadap Mahar Politik Dalam Pembaharuan Hukum Pidana sebagai pisau analisis pada hasil dan pembahasan penelitian yang dianalisis.

\section{Hasil penelitian dan pembahasan}

\subsection{Politik Etis dalam Mahar Politik}

\section{a. Politik Etis Zaman Belanda sampe Era Sekarang}

Politik etis atau dalam bahasa Belanda disebut ethische politiek merupakan gagasan yang lahir dari sebuah peritiwa sistem tanam paksa atau culturstelsel yang menimbulkan banyak korban kelaparan dan keletihan sehingga munculah kritik dari berbagai kalangan baik dari orang-orang non-pemerintahan, praktisi liberal, orang-orang humanis. Sehingga munculah kaum etis yang dipelopori oleh Pieter Brooshooft merupakan seorang wartawan dari Koran De Locomotief dan C.Th van Deventer merupakan seorang politik. Keduanya ternyata telah mampu merubah sikap pemerintahan Belanda untuk lebih memperhatikan nasib para bumiputera.

Politik etis yang dilakukan pada saat itu ternyata hanya menguntungkan dari pihak Bangsa Belanda dan bangsa asing. Seperti kebijakan irigasi yang ternyata hanya mengairi perkebunan Belanda dan bangsa asing. Kemudian dari bidang pendidikan yang hanya diperuntukan bagai golongan orang-orang yang mampu. Serta dalam bidang trasmigrasi dari Jawa ke Sumatra, dan daerah-daerah yang kurang penduduknya, ternyata hanya untuk kepentingan Belanda dalam hal perkebunan milik Belanda. Dari kebijakan yang ada hal ini bertolak belakang dari tujuan adanya politik etis tersebut. Dimana politik etis semestinya bertujuan untuk memegang tanggung jawab moral terhadap kesejahteraan bagi golongan bumiputera.

Sehingga Politik etis saat zaman pemerintahan Belanda menjadi budaya bagi penguasa saat ini. Politik etis yang terjadi saat ini kembali lagi ke era politik etis Belanda hanya saja kemasannya atau kebijakannya yang berbeda. Sehingga tidak dapat menutup kemungkinan segudang persoalan dari berbagai aspek seperti pendidikan, kesehatan, ekonomi, dan lain sebagainya merupakan bentuk dari politik etis di era saat ini.

Perlu pengawasan secara mendalam dari berbagai pihak khususnya dilingkungan eksekutif sebagai pemegang kekuasaan tertinggi, legislatif sebagai pembuat undang-undang dan yudikatif sebagai pelaksanaan undang-undang. Dimana lembaga legislatif yang ingin menjadi anggota dewan di DPR dan DPRD, maka harus melalui tahapan pemilu, begitu pula di lembaga eksekutif yang akan menjadi pemimpin daerah di tingkat propinsi, kabupaten, walikota harus mencalonkan diri melalui partai untuk bisa menjadi Gubernur, Bupati, Walikota. Seperti yang kita ketahui bahwasanya KPK mengungkap kasus-kasus yang terkait Kepala Daerah (Gubernur, Bupati, Walikota) yang telah menjabat yang melakukan penarikan free proyek dari penarikan free yang di peroleh dari legislatif maupun pihak swasta. Dimana kepala daerah tersebut seringkali menyalahgunakan jabatannya sebagai Government Power.

\section{b. Critical Legal Studies terhadap Politik Etis}

Dalam berpolitik perlu adanya etika atau yang biasa kita kenal dengan istilah etika berpolitik. Etika berpolitik ini dibuat guna setiap pejabat untuk bersikap jujur dalam berbuat dan melakukan suatu kebijakan, memiliki sikap yang baik menurut moral bangsa Indonesia. Mengutip pendapat Prihatin Dwihantoro dalam jurnalnya mengatakan bahwa etika ini di 


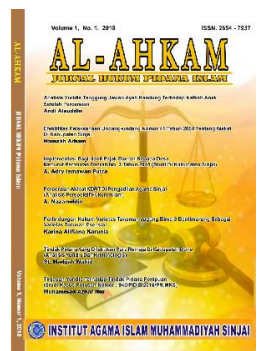

Al-Ahkam

Jurnal Hukum Pidana Islam

Volume 3, No. 1, 2021

ISSN (print) : 2654-7937

ISSN (online) : 2715-0313

Homepage : $\underline{\text { http://journal.iaimsinjai.ac.id/index.php/al-ahkam/index }}$

relisasikan dalam bentuk sikap yang bertatakrama dalam perilaku politik yang toleran, tidak berpura-pura, tidak arogan, jauh dari sikap munafik serta tidak melakukan kebohongan publik, tidak manipulatif dan berbagai tindakan yang tidak terpuji lainnya.

Jurisprudensi model menjelaskan mengenai system aturan-aturan tertulis yang ada ditetapkan dalam bentuk terkodifikasi oleh negara, doktrin yang disusun oleh suatu struktur morfologi yang relevan (arti kata) pertimbangan hokum yang "benar" bagaimana semua konflik dapat dimasukkan (self-referencing), penyelesaian dari perbedaan (self-regulating homeostatis). Adapun dalam sociological model, sebaliknya terdiri dari bebrapa ilmu yakni mengenai fungsi, dan pembenaran bentuk-bentuk control social, bentuk-bentuk pemikiran dan pemahaman hukum jika dihubungkan dengan aturan atau tatanan prinsip legitimasi perkembangan bentuk control social yuridis dengan hak-hak formal, abstrak dan universal. ${ }^{2}$

Berdasarkan pandangan di atas teori hukum dapat dikategorikan dua model hukum yaitu pertama; jurisprudensi model berkaitan dengan asas aturan tertulis, kaidah, norma atau putusan hakim. Bahwasanya legislatif dan eksekutif ketika mencalonkan diri pada saat pemilu pasti membutuhkan uang yang tidak sedikit. Maka dari itu baik calon legislatif dan eksekutif yang akan mencalonkan diri akan meminta bantuan dengan para pihak swasta dengan memberikan janji-janji apabila terpilih nanti akan dimudahkan dalam pengadaan proyek.

Maka hakim tidak dapat menjatuhkan hukuman karena tidak dijelaskan dan disebutkan secara spesifik terkait mahar politik seperti dalam di dalam undang-undang No. 2 Tahun 2008 tentang partai politik, Undang-undang No.7 tahun 2017 tentang Pemilu, namun jika kepala daerah atau lembaga legislatif yang menerima fee dari pihak swasta hakim hanya dapat menjerat dengan undang-undang korupsi yakni Undang-undang No.31 tahun 1999 jo no 20 tahun 2001. Sehingga selama ini hakim tidak menjerat para pelaku tersebut dan bebas mengikuti pemilu tersebut, hal inilah maka KPU daerah sebgai tonggak pintu masuk awal calon legislatif maupun calon kepala daerah dengan bebasnya mencalonkan diri.

Kedua menggunakan socialogi model terkait fenomena yang terjadi di masyarakat menjelang pemilu pada H-1 banyaknya serangan fajar yang dilakukan oleh calon legislatif dan calon kepala daerah, serta kader pendukung kepada masyarakat seperti pembagian sembako, dan lain sebagainya yang bertujuan untuk dapat memilih calon legilatif dan calon kepala daerah. Namun selama ini masyarakat menganggap sebagai suatu yang wajar, dan dirasa tidak melanggar hukum, masyarakat tidak mengetahui bahwa pembagian semabako menjelang H-1 sesungguhnya melanggar hukum. Seandainya masyarakat mengetahui bahwa perbuatan menerima sembako dari calon legislatif dan calon Kepala daerah merupakan tindakan calon legislatif melanggar, maka dapat melaporkan kepada Bawaslu untuk membatalkan calon legislatif dan calon kepala daerah. Kemudian Bawaslu nantinya akan memproses ke PTUN untuk sanksi adminstrasi

\section{c. Pelaksanaan Politik Etis Dalam Pembaharuan Hukum Pidana Mahar Politik}

Secara umum hukum pidana dapat diartikan menjadi dua pengertian, yaitu disebut hukum pidana objektif (ius poenale) dan sebagai hukum subjektif (ius puniend). Hukum

${ }^{2}$ Otje Salman, dan Anthon F. Susanto, Teori Hukum (mengingat, mengumpulkan dan membuka kembali), (Bandung: Refika Aditama, 2004) 51-52. 


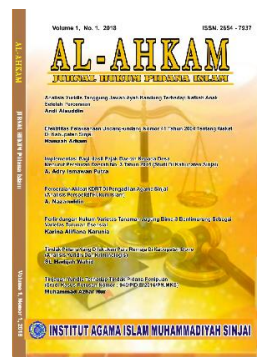

Al-Ahkam

Jurnal Hukum Pidana Islam

Volume 3, No. 1, 2021

ISSN (print) : 2654-7937

ISSN (online) : 2715-0313

Homepage : http://journal.iaimsinjai.ac.id/index.php/al-ahkam/index

pidana dalam pengertian secara objektif yaitu sekumpulan peraturan yang mengandung larangan-larangan atau keharusan-keharusan dimana terhadap pelanggarnya diancam dengan hukuman pidana. Hukum pidana dalam arti objektif berupa peraturan yang isinya laranganlarangan atau batasan yang boleh dilakukan oleh siapa pun dan memiliki sanksi berupa ancaman pidana apabila dilanggar.

Sedangkan hukum dalam arti subjektif (ius puniendi), menurut Jan Remmelik yakni hak untuk memidana. Hak negara memiliki kekuasaan dalam menuntut, menjatuhkan dan mengeksekusi hukum pidana pada siapa saja yang melanggar pidana. Tujuan dari hukum pidana yaitu menegakkan tertib hukum dan melindungi masyarakat hukum.

Mahar politik di Indonesia selama ini telah lama ada, namun dalam Undang-Undang No.7 tahun 2017 tentang Pemilu dan Undang-Undang No. 2 tahun 2008 tentang Parpol belum ada yang mengatur terkait secara khusus mahar politik. Undang-Undang No. 7 tahun 2017 tentang Pemilu pasal 327 ayat (1) dan (2) tentang Pemilu terdapat batasan dalam pemberian dana kampanye oleh perseorangan maupun kelompok, perusahaan, atau badan usaha nonpemerintah yakni Rp 25.000.000.000 (dua puluh lima miliar rupiah). Setiap peserta pemilu yang menggunakan kelebihan sumbangan, tidak melaporkan kelebihan sumbangan kepada KPU, dan atau tidak menyerahkan kelebihan sumbangan kepada kas negara paling lambat 14 (empat belas) hari setelah masa kampanye pemilu berakhir dipidana dengan pidana penjara paling lama 2 (dua) tahun dan denda paling banyak Rp 500.000.000,00 (lima ratus juta rupiah).

Undang-Undang No.2 tahun 2008 tentang Partai Politik pasal 40 ayat (3) mengatakan "Partai Politik dilarang menerima dari atau memberikan kepada pihak asing dalam bentuk apa pun yang bertentangan dengan peraturan perundang-undangan, melebihi batas yang ditentangkan dalam peraturan perundang-undangan, menerima sumbangan berupa uang, barang, ataupun jasa dari pihak mana pun tanpa mencantumkan identitas yang jelas, meminta atau menerima dana usaha milik negara, badan usaha milik daerah, dan badan usaha milik desa atau dengan sebutan lainnya, dan menggunakan fraksi di Majelis Permusyawarat Rakyat, Dewan Perwakilan Rakyat, Dewan Perwakilan Rakyat Daerah Provinsi, dan Dewan Perwakilan Rakyat Daerah kabupaten/kota sebagai sumber pendanaan Partai Politik.

Undang-Undang No.2 tahun 2008 pasal 40 ayat (3) tidak ditemukan larangan mengenai praktik mahar politik. Kedua Pasal diatas tidak ditemukan larangan yang menyebutkan secara spesifik mengenai mahar politik. Dalam pasal 327 ayat 1 dan 2 padaU ndang-Undang No. 7 tahun 20017 tentang Pemilu tersebut hanya menjelaskan mengenai dana kampanye. Dana kampanye digunakan untuk peserta pemilu yang sudah terdaftar. Sedangkan mahar politik merupakan ongkos supaya diusung oleh parpol.

Dana kampanye merupakan aktivitas yang mengacu pada penggalangan dana dan pengeluaran kampanye pada persaingan pemilu untuk mengenalkan visi-misi dari peserta pemilu. Dana politik dan mahar politik adalah sesuatu yang berbeda, namun dana kampanye ini bisa menjadi peluang besar dalam praktik mahar politik. Maka dari itu diperlukan pembaharuan hukum pidana terkait pasal mahar politik secara tegas dan hukumannya haruslah lebih berat sehingga meberikan efek jera bagi pelaku-pelaku mahar politik. Hal ini karena setiap tahunnya terjadi kasus mahar politik diseluruh daerah Indonesia ketika 


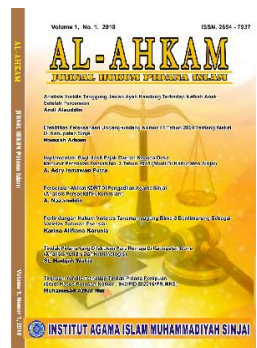

Al-Ahkam

Jurnal Hukum Pidana Islam

Volume 3, No. 1, 2021

ISSN (print) : 2654-7937

ISSN (online) : 2715-0313

Homepage : http://journal.iaimsinjai.ac.id/index.php/al-ahkam/index

mendekati pemilu dan menimbulkan sikap ketidak perdulian masyarakat akan wakil rakyat yang akan dipilinya berujung pada rusaknya demokrasi dan cita-cita bangsa Indonesia.

Selama tidak ada peraturan secara tegas dalam Undang-Undang pemilu terkait mahar politik maka selama itu pula seluruh Partai Politik akan menghalalkan termasuk melakukan praktik mahar politik pada bakal calon yang diusungnya dapat menang dalam pemilu dan tentu saja hal ini akan menguntungkan bagi bakal calon dan partai politik yang mengusungnya dan pihak-pihak lainnya yang terkait dalam mahar politik tersebut sehingga nantinya menimbulkan praktik KKN yang berkepanjangan.Menurut Muladi dan Barda Nawawi, pidana merupakan suatu pengenaan penderitaan atau nestapa atau akibat-akibat lain yang tidak menyenangkan diberikan dengan sengaja oleh orang atau badan yang mempunyai kekuasaan yang dikenakan pada seseorang yang telah melakukan tindak pidana menurut undang-undang.

Pelaku praktik mahar politik perlu di pidana sebagai penebusan akan kesalahannya dan juga agar pelaku menjadi pribadi yang tidak akan melakukan praktik mahar politik lagi. Pemidanaan juga dapat menjadi pencegahan kejahatan yaitu sebagai pelajaran bagi masyarakat terutama para politisi agar tidak melakukan praktik mahar politik. Praktik mahar politik akan menurunkan kualitas dari bakal calon yang mengikuti Pemilu. Partai politik seakan-akan hanya mencari keuntungan dari ongkos yang diberikan oleh bakal calon yang mengikuti pemilu. Partai politik hanya memikirkan seberapa banyak ongkos yang ia dapatkan, dan tidak mementingkan kualitas dari bakal calon yang diusung oleh partai politik.

Sehingga praktik mahar politik dalam pembaharuan pidana nantinya, harus jelas subtansi atau kriteria mahar politik. Siapa saja yang tersangkut mahar politik, bahkan partai politik yang ikut terlibat juga harus mendapatkan sanksi. Hal ini karena praktek mahar politik bukan hanya tindak pidana umum tetapi merupakan tindak pidana khusus, sama dengan tindak pidana korupsi. Kualitas calon yang terpilih yang melakukan praktek mahar politik ini akan mempengaruhi keberhasilan kinerja dalam pemerintahan. Kesejahteran rakyat pun juga akan terancam. Para pelaku praktik mahar politik dikhawatirkan akan melakukan tindak pidana korupsi setelah menjadi pejabat negara. Maka perlu adanya tindakan pencegahan bagi masyarakat lainnya. Pencegahan ini bisa dilakukan dengan pertanggungjawaban dari pelaku praktik mahar politik yaitu berupa pemberian sanksi pidana, dalam pembaharuan hukum pidana dalam Undag-Undang No.7 tahun 2017 tentang Pemilu dan Undang-UndangNo. 2 tahun 2008 tentang Partai Politik.

Pembaharuan hukum pidana terkait mahar politik perlu dilakukan dengan beberapa alasan yang melandasinya, yaitu dari sumber hukum materil dan sumber hukum formil

\section{d. Sumber hukum materil terdiri dari:}

1) Landasan filosofis

Peraturan perundang-undangan di Indonesia harus berlandaskan pandangan filosofis Pancasila. Praktik mahar politik tidak mencerminkan nilai-nilai religiusitas bangsa, hak asasi manusia, nilai-nilai kepentingan bangsa, nilai-nilai demokrasi dan kedaulatan rakyat, dan nilai keadilan sosial.

2) Landasan yuridis

Dari segi materil perlu pembaharuan terhadap Undang-Undang No.7 tahun 2017 tentang Pemilu dan Undang-Undang No. 2 tahun 2008 tentang Partai Politik. Landasan yuridis harus memenuhi prinsip demokrasi, sedangkan 


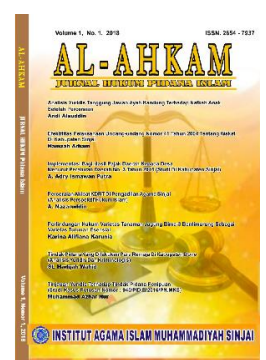

Al-Ahkam

Jurnal Hukum Pidana Islam

Volume 3, No. 1, 2021

ISSN (print) : 2654-7937

ISSN (online) : 2715-0313

Homepage : http://journal.iaimsinjai.ac.id/index.php/al-ahkam/index

praktik mahar politik dapat mencederai dan merusak nilai-nilai demokrasi. Alasan inilah yang juga harus dipertimbangkan dalam pembaharuan hukum pidana.

3) Landasan sosiologis

Masyarakat membutuhkan peraturan yang dapat meningkatkan kesejahteraannya. Bakal calon peserta pemilu yang melakukan praktik mahar politik ketika telah menjadi wakil rakyat, mereka tidak bisa menjalankan secara optimal dalam mencapai tujuan kesejahteraan rakyat. Mereka cenderung mengabaikan aspirasi rakyat serta membuat kebijakan yang tidak pro rakyat. Untuk menghindari akibat-akibat dari praktik mahar politik ini maka diperlukan pembaharuan hukum pidana terkait mahar politik.

\section{e. Sumber hukum formil}

Perlunya pembaruan hukum pidana dari segi sumber hukum formil terkait Undang-Undang No 7 tahun 2017 tentang Pemilu pasal 327 ayat 1 dan 2 tentang Pemilu terdapat batasan dalam pemberian dana kampanye oleh perseorangan maupun kelompok, perusahaan, atau badan usaha nonpemerintah yakni $\mathrm{Rp} 25.000 .000 .000$ (dua puluh lima miliar rupiah). UndangUndang No.2 tahun 2008 pasal 40 ayat (3) Partai Politik dilarang menerima dari atau memberikan kepada pihak asing dalam bentuk apa pun yang bertentangan dengan peraturan perundang-undangan, dalam pasal initidak ditemukan larangan mengenai praktik mahar politik.Pasal 327 ayat 1 dan 2 Undang-Undang No. 7 tahun 2017 tentang Pemilu tersebut hanya menjelaskan mengenai dana kampanye.

Maka makna dan hakikat pembaharuan hukum pidana haruslah melalui dua pendekatan sebagai berikut:

1) Dilihat dari sudut pendekatan kebijakan

a) Sebagai bagian dari kebijakan sosial, pembaharuan hukum pidana pada hakikatnya merupakan bagian dari upaya untuk mengatasi masalah-masalah sosial (termasuk masalah kemanusiaan) dalam rangka mencapai atau menunjang tujuan nasional (kesejahteraan masyarakat dan sebagainya).

b) Sebagai bagian dari kebijakan kriminal, pembaharuan hukum pidana pada hakikatnya merupakan bagian dari upaya perlindungan masyarakat (khususnya upaya penanggulangan kejahatan).

c) Sebagai bagian dari kebijakan penegakan hukum, pembaharuan hukum pidana pada hakikatnya merupakan bagian dari upaya memperbaharui substansi hukum (legal substance) dalam rangka lebih mengefektifkan penegakan hukum.

Bahawasanya dilihat dari segi kebijakan lembaga legislatif berperan dan ikut andil dalam merumuskan serta merevisi Undang-Undang No. 7 tahun 2017 pasal 327 ayat (1) dan (2) tentang Pemilu dan Undang-Undang No. 2 tahun 2008 pasal 40 ayat (3)tentang Partai Politik. dari segi kebijakan kriminal diperlukan pembaharuan hukum pidana untuk menerapkan sanksi yang tegas, dalam pemeberian mahar politik dari bakal calon pihak pengusaha maupun pihak lainnya untuk membiayai dana kampanye dana pemilu. Supaya masyarakat tidak dirugikan oleh oknum yang melakukan praktik mahar politik dan tidak tertipu oleh janji-janji yang ungkapkan oleh bakal calon pemilu. dari segi penegakkan hukum, ketika bakal calon terbukti melakukan mahar politik ketika akan mendaftar di KPU maka sudah pasti KPU akan tidak meloloskan bakal calon tersebut. Namun ketika bakal calon tersebut telah lulus verifikasi di KPU ternyata baru terbukti melakukan mahar politik maka Bawaslu akan memberikan sanksi kepada bakal calon tersebut. Baik KPU dan Bawaslu akan melaporkan ke KPK apabila ada bakal calon terbukti melakukan mahar politik dan akan dituntut secara pidana di Pengadilan Negeri.

2) Dilihat dari sudut pendekatan nilai: 


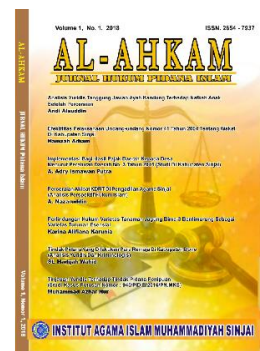

Al-Ahkam

Jurnal Hukum Pidana Islam

Volume 3, No. 1, 2021

ISSN (print) : 2654-7937

ISSN (online) : 2715-0313

Homepage : http://journal.iaimsinjai.ac.id/index.php/al-ahkam/index

Pembaharuan hukum pidana pada hakikatnya merupakan upaya melakukan peninjauan dan penilaian kemabali ("reorientasi dan reevaluasi") nilai-nilai sosiopolitik, sosiofilosofis, dan sosiokultural yang melandasi dan memberi isi terhadap muatan normatif dan substansif hukum pidana bukanlah pembaharuan ("reformasi") hukum pidana.

Pembaruan hukum pidana memuat normatif dari sumber hukum materil yang terdiri dari landasan yuridis, sosiologis, filosofis sedangkan sumber hukum formil perlunya pembaharuan hukum pidana untuk memberian sanksi yang tegas kepada pelaku mahar politik pada UndangUndang No. 7 tahun 2017 pasal 327 ayat (1) dan (2) tentang Pemilu dan Undang-Undang No. 2 tahun 2008 pasal 40 ayat (3) tentang Partai Politik.

Negara Indonesia merupakan negara hukum. Sebagai suatu negara hukum, sudah selayaknya prinsip-prinsip dari suatu negara hukum harus dihormati dan dijunjung tinggi. Salah satunya adalah diakuinya prinsip peradilan yang benar dan tidak memihak. Kekuasaan kehakiman menurut UUD Negara Republik Indonesia Tahun 1945 merupakan kekuasaan yang merdeka yang dilakukan oleh sebuah Mahkamah Agung dan badan peradilan di bawahnya, dan oleh sebuah Mahkamah Konstitusi, untuk menyelenggarakan peradilan guna menegakkan hukum dan keadilan. ${ }^{3}$

Dalam suatu negara hukum, tata kehidupan berbangsa dan bernegara haruslah berpedoman pada nprma-norma hukum. Dalam rangka menegakkan dan menjamin berjalannya aturan-aturan hukum seperti yang diharapkan diperlukan adanya kekuasaan kehakiman yang kuat dan mandiri. Kekuasaan kehakiman (judicative power) ini bertugas untuk menegakkan dan mengawasi berlakunya peraturan perundang0undangan yang ada. Di Indonesia kekuasaan kehakiman dilaksanakan oleh sebuah Mahkamah Agung dan badan peradilan yang berada di bawahnya dalam lingkungan peradilan umum, lingkungan peradilan agama, lingkungan peradilan militer, lingkungan peradilan tata usaha negara, dan oleh sebuah Mahkamah Konstitusi (Pasal 24 ayat (2) UUD 1945 setelah perubahan). ${ }^{4}$

Kemandirian kekuasaan kehakiman atau kebebasan hakim merupakan asas yang sifatnya universal, yang terdapat dimana saja dan kapan saja. Asas ini berarti bahwa dalam melaksanakan peradilan, hakim itu pada dasarnya bebas, yaitu bebas dalam memeriksa dan mengadili perkara dan bebas dari campur tangan atau turun tangan kekuasaan ekstra yudisil. Jadi pada dasarnya dalam memeriksa dan mengadili, hakim bebas untuk menentukan sendiri cara-cara memeriksa dan mengadili. Kecuali itu pada dasarnya tidak ada pihak-pihak, baik atasan hakim yang bersangkutan maupun pihak ekstra yudisil yang boleh mencampuri jalannya siding peradilan.

Memberikan tentang pelaksanaan kemandirian kekuasaan kehakiman, perlu ada parameter yang jelas yang menjadi tolok ukur mendiri atau tidaknya lembaga peradilan tersebut dalam penelitian ini. Kemandirian kekuasaan kehakiman di sini dapat dibedakan menjadi tiga macam, yaitu kemandirian lembaganya, kemadirian proses peradilannya dan kemadirian hakimnya sendiri. Secara lebih jelas, dapat dilihat uraian tentang tiga macam tipe kemandirian kekuasaan kehakiman dibawah ini. ${ }^{5}$

\footnotetext{
${ }^{3}$ Bambang Sutiyoso dan Sri Hastuti Puspitasari, Aspek-Aspek Perkembangan Kekuasaan Kehakiman di Indonesia, (Yogyakarta: UII Press, 2005), 11.

${ }^{4}$ Ibid., 14.

${ }^{5}$ Ibid., 52.
} 


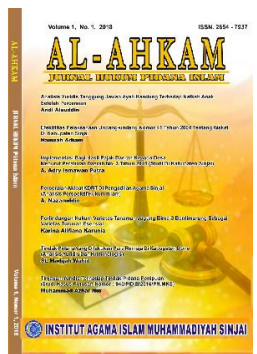

\section{Al-Ahkam}

Jurnal Hukum Pidana Islam

Volume 3, No. 1, 2021

ISSN (print) : 2654-7937

ISSN (online) : 2715-0313

Homepage : http://journal.iaimsinjai.ac.id/index.php/al-ahkam/index

a. Kemandirian lembaganya/institusi

b. Kemandirian proses peradilan

c. Kemandirian hakim

Bahwasanya lembaga yudikatif harus besifat mandiri bebas dari lembaga legilatif dan lembaga eksekutif. Seperti kasus Akil Muchtar terjerat kasus suap atau menerima gratifikasi atas perkara yang ditanganinya dengan memenangkan gugatan dari tenggugat. Gugatan tersebut berupa proses pemilihan kepala daerah di Sulawesi yang digugat oleh kepala daerah yang kalah dalam pemilihan karena seharusnya menang kalah dalam pemilu kemudian terjadinya penggelembungan suara dalam pemilu. Dengan demikian lembaga eksekutif tidak boleh campur tangan di wilayah lembaga yudikatif karena Akil Muchtar merupakan salah satu wakil hakim yang menangani sengketa pemilu. Sanksi yang diberikan oleh hakim harus sesuai dengan perundang-undangan yang ada, hakim tidak memihak pihak manapun, tidak boleh mendapat tekanan dari pihak legislatif dan eksekutif supaya dapat memberikan putusan seadiladilnya

\section{Kesimpulan}

1. Politik etis dalam mahar politik Berdasarkan pandangan di atas teori hukum dapat dikategorikan dua model hukum yaitu pertama; jurisprudensi model berkaitan dengan asas aturan tertulis, kaidah, norma atau putusan hakim. maka hakim tidak dapat menjatuhkan hukuman karena tidak dijelaskan dan disebutkan secara spesifik terkait mahar politik seperti dalam di dalam undang-undang No. 2 Tahun 2008 tentang partai politik, Undang-undang No.7 tahun 2017 tentang Pemilu. Kedua menggunakan socialogi model terkait fenomena yang terjadi di masyarakat menjelang pemilu pada H-1 banyaknya serangan fajar yang dilakukan oleh calon legislatif dan calon kepala daerah, serta kader pendukung kepada masyarakat seperti pembagian sembako, dan lain sebagainya yang bertujuan untuk dapat memilih calon legilatif dan calon kepala daerah. .

2. Pelaksanaan Politik Etis Dalam Pembaharuan Hukum Pidana Mahar Politik ; Pembaharuan hukum pidana terkait mahar politik perlu dilakukan dengan beberapa alasan yang melandasinya, yaitu ; Sumber hukum materil terdiri dari: Landasan filosofis ; Peraturan perundang-undangan di Indonesia harus berlandaskan pandangan filosofis Pancasila. Landasan yuridis ; Dari segi materil perlu pembaharuan terhadap Undang-Undang No.7 tahun 2017 tentang Pemilu dan Undang-Undang No. 2 tahun 2008 tentang Partai Politik. Landasan yuridis harus memenuhi prinsip demokrasi, Landasan sosiologis; Untuk menghindari akibat-akibat dari praktik mahar politik ini maka diperlukan pembaharuan hukum pidana terkait mahar politik. Dari Sumber hukum formil Perlunya pembaruan hukum pidana dari segi sumber hukum formil terkait Undang-Undang No 7 tahun 2017 tentang Pemilu pasal 327 ayat 1 dan 2 tentang Pemilu terdapat batasan dalam pemberian dana kampanye oleh perseorangan maupun kelompok, perusahaan, atau badan usaha non pemerintah. pasal initidak ditemukan larangan mengenai praktik mahar politik.Pasal 327 ayat 1 dan 2 Undang-Undang No. 7 tahun 2017 tentang Pemilu tersebut hanya menjelaskan mengenai dana kampanye. 


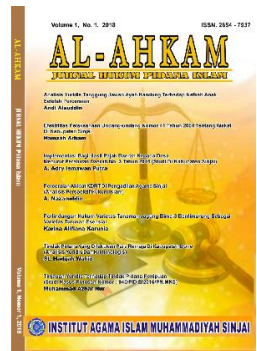

Al-Ahkam

Jurmal Hukum Pidana Islam

Volume 3, No. 1, 2021

ISSN (print) : 2654-7937

ISSN (online) : :2715-0313

Homepage : $\underline{\text { http://journal.iaimsinjai.ac.id/index.php/al-ahkam/index }}$

\section{Daftar Pustaka}

Dwihantoro. Prihatin Vol. 4. No. 2. 2013.” Etika Dan Kejujuran Dalam Berpolitik. Jurnal Politika .

Salman, Otje dan Susanto, Anthon F. .2004. Teori Hukum. Bandung: Refika Aditama.

Susilo, Agus . Isbandiyah, . Vol.6. No. 2. 2018."Politik Etis dan Pengaruhnya Bagi Lahirnya Pergerakan Bangsa Indonesia". Jurnal Historia

Sutiyoso, Bambang dan Puspitasari, Sri Hastuti. 2005. Aspek-Aspek Perkembangan Kekuasaan Kehakiman di Indonesia. Yogyakarta: UII Press.

Usman, Analisis Perkembangan Teori Hukum Pidana, Jurnal Ilmu Hukum.

Widjojanto, Bambang. Politik Etis Dalam Pencegahan Tindak Pidana Korupsi. 2 Maret 2019. dalam Seminar Nasional Universitas Muhammadiah Ponorogo.

\section{Peraturan Perundang-undangan}

1. Undang-Undang Nomor 7 Tahun 2017 Tentang Pemilu

2 Undang-Undang Nomor 2 Tahun 2008 Tentang Partai Politik

2. Undang-Undang Nomor 31 Tahun 1999 tentang Korupsi

3. Undang-Undang Nomor 20 Tahun 2001 Tentang Pemberantasan Tindak Pidana Korupsi

4. Undang-Undang Nomor 48 Tahun 2009 Tentang Kekuasaan Kehakiman

Internet

Anantarigan.2020.https; /www.blolg.spot/Politik-Etis//01-desember-2020.// 